\title{
CULTURAL CONSTRAINTS ON THE DELIVERY OF HIV/ AIDS PREVENTION IN IRELAND
}

\author{
FIONA SMYTH \\ Department of Geography, University of Manchester, Oxford Road, Manchester M13 9PL, U.K.
}

\begin{abstract}
HIV appeared in Ireland following an opiate epidemic in the early 1980s. Initially, however, the gay community mounted the only response to the spread of the virus while the implementation of early actions by the government was hampered by the constructions of the disease within Irish society. This paper considers the influence of the religious hierarchy in both the development of AIDS policy and in the shaping of public perceptions of the disease and those affected. A qualitative methodology is used to examine the role of such cultural constraints in an evaluation of the social context within which the prevention of HIV infection occurs. Three key issues pertinent to the policy context in Ireland are explored in depth. These are the role of the Catholic Church, the influences on health education programmes, particularly information giving, and the development of services and other interventions. These findings are discussed within the social and political contexts in which health policy is formulated. (C) 1998 Published by Elsevier Science Ltd. All rights reserved
\end{abstract}

Key words-HIV/AIDS, Ireland, Prevention, Culture, Catholicism

\section{INTRODUCTION}

Almost without exception, governments around the world have been slow to react to the emerging epidemic of HIV and AIDS because they fear the political implications of becoming involved with a disease that raises a variety of difficult social and moral issues (Kirp and Bayer, 1992). In many countries, social and cultural values have served to reinforce risk taking behaviour by the denunciation of gay sexuality or intravenous drug use. Voluntary and statutory workers have, therefore, found themselves in difficult positions whereby their governments have been reluctant to endorse the services that they provide because of the nature of the disease and those who are affected (Krieger and Margo, 1994). Intervention strategies have largely focused on individual behaviour and, particularly, on risk avoidance with schemes that encourage drug users to adopt safer injecting habits or that advocate alternative sexual practices to gay men. The focus of these interventions has been on empowering individuals through increasing their awareness of the disease and promoting personal responsibility among those who are infected or believed to be at high risk (Smyth et al., 1996a).

Prior to these tenuous responses, the epidemic in Ireland emerged in 1982 with diagnoses of AIDS in

*Of the total reported AIDS cases (to end December 1995), $43 \%$ were classified as intravenous drug users, $33 \%$ as gay men; $12 \%$ as heterosexuals, $6 \%$ as haemophiliacs, $2 \%$ as children born to IVDUs and the remaining groups comprised less than $2 \%$ of total AIDS cases. two gay men who had made sexual contacts abroad (Freedman, 1989; Smyth et al., 1996b). This national epidemic, however, soon began to differ from its North European neighbours as the incidence among gay men was superseded by HIV infections among the populous drug using communities in the inner city districts of Dublin. Statistics released by the Department of Health, for example, counting cumulative case totals to the end of 1995 , reported 498 cases of AIDS amongst whom $43 \%$ were classified as intravenous drug users (IVDUs) (Department of Health, 1995).* Consequently, the composition of Irish AIDS incidence is most similar to areas of Southern Europe like Italy, Spain and the South of France, where $30-70 \%$ of HIV infection has been attributed to IVDUs (WHO-EC, 1991).

Such national contrasts, however, are made according to particular behaviours that encourage fragmented social constructions of the epidemic by risk group (Dyck, 1990; Kearns, 1996). Moreover, such distinctions ignore the universality of our susceptibility to HIV infection and, for this reason, might mask broader social and cultural processes that impinge upon the transmission risk. Religious beliefs and customs, for example, may not necessarily concur with secular proposals aimed at preventing the exchange of seropositive body fluids. In Ireland, such contradictions might be expected to be especially pronounced because the interpretation of Catholic doctrine is more literal than elsewhere and is intertwined with a unique national identity. Accordingly, this paper applies a qualitative methodology to assess the influence of this ideology on 
the delivery of services for those with HIV/AIDS. It begins by discussing the tensions between the major interventions against HIV infection and the tenets of Irish Catholicism. Then, the evolution of services is evaluated within this perspective. The results highlight the specific cultural constraints that have been placed on prevention in Ireland through an analysis of interviews with those involved in the provision of services. The discussion sets these findings within the context of the evolving epidemic.

\section{THE CULTURAL SETTING}

The Irish context provides an arena in which the social constructions of the epidemic have become particularly well developed. In comparison to many other catholic countries, Ireland shows an unusual degree of homogeneity in its religion (Whyte, 1984). More than $90 \%$ of the Irish population identify themselves as "Catholic" and, as a result, the Church has long been afforded a dominant role in the country's political culture (Fogarty et al., 1984). Indeed, the Catholic hierarchy have succeeded in dominating public discourse on a wide range of moral issues but, particularly, in the area of sexual morality (Butler and Woods, 1992). In 1937, for example, the constitution was amended to give the Catholic Church a "special position" (Article 44) because, at that time, there was a marked consensus in Irish society that demanded that Catholic values be maintained and, if necessary, that they be reinforced through state legislation and hence abortion, contraception and homosexuality were all prohibited by statute for a considerable period of time.* Indeed, the Church made it clear to politicians in the past that "it was their duty to ensure that legislation should direct men and women to lead a moral life and that Catholic values should permeate society" (Cooney, 1986, p. 13). A bill introduced in 1971 calling for a change to the law on contraceptive availability, was not even given a first reading in the Dáil (Irish parliament) following the comments of the Archbishop of Dublin:

Given the proneness of our human nature to evil, given the encitement of bodily satisfaction, given the widespread modern incitement to unchastity, it must be evident that an access to hitherto unlawful contraceptive devices will prove a most certain occasion of sin (quoted in Cooney, 1986, p. 34).

Until recently, there has been relatively little outward criticism of the clergy and no substantial anticlerical political movement has developed in response to their influence on policy issues. However, over the course of the last few decades, the population of Ireland has become increasingly stratified primarily as a result of the economic changes that

*Acts of anal intercourse were illegal in Ireland until a change to the law in 1993. have occurred within the country (Trench and Brennan, 1980). More specifically, these developments have laid the foundations for wider changes that have included an ideological shift away from the traditions of Catholicism and nationalism among some of the younger generations (Peillon, 1982). Indeed, in the 1980s, a degree of generational conflict started to emerge between those who lived according to the traditional ideologies of Catholicism and nationalism, on the one hand, and those who advocated liberalism and materialism on the other (see O'Leary and Hesketh, 1988; Ryan, 1984). Over time, the affluence generated by economic changes in the 1960s has proved as powerful at integrating certain sectors of the population as the traditional ideologies were in earlier years. Nonetheless, the emerging tensions and disparities between the groups have created restlessness and the alienation of some of the population who, through unemployment, have not shared in this new found wealth.

In the past, a strong feature of Irish society has been the high level of net out-migration, usually to Britain, primarily, as a result of the limited economic opportunities available at home. However, the new generation of Irish have not been as willing to accept emigration as the "way out" and, indeed, have not had the incentive to do so, given the rising levels of welfare payments in the Republic since their joining the European Community in 1973. Instead, there has emerged a growing sector of the population who have become disillusioned with life in Ireland, partially because of the authoritarian nature of society but also because of their failure to share in the economic benefits of industrial developments since the 1950s (Butler, 1991; Cooney, 1986). It was among this community that intravenous opiate use emerged as a significant risk factor for HIV infection and, indeed, Dublin is now reported to have a drugs problem proportionately equivalent to that in New York (Coogan, 1987), primarily among the young, long-term unemployed population living in the inner city districts of the capital (Dean et al., 1984, 1985, 1992). Recently, research has shown that the majority of these drug users consume their heroin intravenously and share their needles with other users (O'Hare and O'Brien, 1992), behaviour which places them at high risk for HIV infection.

It was within this context that a response to the emerging epidemic had to be developed. Ireland was, in many ways, in a unique situation in terms of the pre-existing structures that influenced the development of AIDS services. Throughout the 1980s, homosexuality remained illegal and, therefore, health officials did not respond to the early cases of AIDS amongst gay men. Similarly, until 1993, condoms were only legally available under restricted conditions to married couples and even now the Catholic hierarchy refuses to acknowledge their role in limiting the spread of HIV infection. In 
the light of the AIDS epidemic, therefore, early Irish health educators felt obliged to be mindful in their advocacy of the condom as a means of preventing the transmission of HIV or, indeed, of encouraging safer gay sex which could be construed as condoning criminal behaviour (Butler and Woods, 1992).

The reaction to the emerging HIV/AIDS epidemic was relatively slow. The Irish health system still reflects the Catholic social principle of subsidiarity whereby the Church maintains the desirability of leaving as many functions as possible to bodies lesser than the state including families, community associations and other professional and vocational organisations (Butler and Woods, 1992; Whyte, 1984). As a result, the country has never developed a welfare state that is comparable with that which exists in Britain and the response to AIDS has, therefore, largely emerged from a poorly funded voluntary sector. The importance placed on the family unit in Irish society has served to reinforce existing pressures on the families of many who have developed AIDS. Among the drug using communities, for example, multiple family infection is relatively common while gay men have found that the prejudice surrounding their sexuality has hindered their care in the community.

\section{PROVIDING SUPPORT AND SERVICES}

Table 1 lists each of the organisations in Ireland that offer assistance in some form to people affected by HIV or AIDS. Some groups concentrate specifically on services related to the condition, such as AIDS Help West, the Baggot Street Clinic and Dublin AIDS Alliance. Others offer more general help to people who are accessing other services but for whom HIV may be an issue, such as drug users at the Ana Liffey and Merchant's Quay drugs projects and haemophiliacs at the National Haemophilia Treatment Centre. These services are either provided by the state through the statutory sector or through individuals and organisations in the voluntary sector. The table lists both the services that are offered, their health sector, their main client groups and the location of each service. The early 1990s have seen far-reaching changes within many of these organisations as a result of amendments to the law, government policy and the organisation of services for HIV/AIDS which have been accompanied by the dissolution of some alliances and establishment of others. These changes have been marked by increased tensions and rivalries between some groups and the emergence of a disparate voluntary sector. Here, I examine the issues surrounding these changes and consider their influences on the development of intervention strategies.

The early cases of AIDS in Ireland were reported from gay and bisexual men in 1982 (O'Keefe et al., 1983 ) and it was from the politicised gay population of Dublin that the first direct response to HIV and AIDS in Ireland emerged. In January 1985, a meeting was held in Cork for Irish gay activists who were concerned about the fear being generated around AIDS by the British media in newspapers that were also widely read in Ireland (Quinlan, 1991). Gay Health Action (GHA) was initially established on a national basis with the intention of providing "clear and accurate information on AIDS and related issues to the gay community, the media, medical profession and health workers, Trade Unions and the general public" (GHA, 1986, p. 2). Together with its sister group, Lesbian Health Action, GHA undertook publicity and lobbying work, HIV education and operated the first AIDS telephone service. However, the work of the group was limited by a lack of economic resources. The legal status of acts of anal intercourse at that time stopped the government from initiating and funding prevention campaigns specifically targeted at gay men. The Department of Health offered the organisation no funding throughout its existence because this resource would be seen as condoning such acts. The group did manage to obtain IR£1500 from the government in 1985 to produce its first general AIDS information leaflet but, after this, it produced over 300,000 pieces of literature and posters without any additional support from the authorities (Quinlan, 1991). Although the group eventually disbanded in 1990, it was instrumental in founding a number of other voluntary agencies in Ireland including the AIDS Helpline, Cáirde and AIDS Action Alliance.

Cáirde (meaning "friends" in Irish) is a befriending organisation offering buddying to persons directly or indirectly affected by HIV and AIDS. The initial training for volunteers was given by two doctors from the American organisation, Gay Men's Health Crisis (Berkeley, 1990). In the summer of 1985, they were in Ireland to give a paper to the World Health Organisation Conference and they offered a weekend of training in grief and bereavement issues to those interested in AIDS work. The early service was modelled on the one to one befriending or buddying scheme, introduced to San Francisco by the Shanti Project, that has since been replicated by many other groups worldwide. Cáirde is the only organisation in the Irish voluntary sector which offers home care to people affected by HIV/AIDS (including supplementary nursing care and pain relief) while also offering support to partners, families and friends who have been affected by the disease.

In contrast, Body Positive is a self-help organisation for people in Ireland who are infected with HIV. The Irish organisation is independent but forms part of an international network of Body Positive groups. Apart from its information and support services for those who are positive, the group also facilitates talks, by $\mathrm{HIV}+$ people, in 
schools and community-based organisations. Body Positive offers people with HIV the opportunity to represent themselves rather than being represented by medical staff and social workers. The group ensures that all their major decisions are made by the HIV + members of the organisation, although there is also a management team, involved in such issues as funding, who are not necessarily antibody positive. In the U.K., Body Positive is seen largely as a gay organisation but, in Dublin, most clients are current and ex-drug users.

AIDS Action Alliance was founded by Gay Health Action in 1987. It was intended to serve as an umbrella organisation for all the groups in the voluntary sector and to help develop the non-statutory response to AIDS in Ireland. By sharing limited resources, including a building, photocopying and telephones, the group began to expand rapidly. The voluntary sector came to be represented by AIDS Action Alliance and one voice was effectively able to speak for all of the groups. The expansion, however, became cumbersome and the divergent needs of the different areas within Ireland eventually led to the regionalisation of the AIDS Action Alliance from 1990. The organisation still maintains contacts with the other groups but now Dublin AIDS Alliance, Cork AIDS Alliance, AIDS Help West (in Galway) and Limerick AIDS Alliance are autonomous bodies.

While the voluntary sector was responding to the demands of HIV and AIDS in the mid1980 s, the statutory sector continued to remain ambivalent. As late as 1986, the newly formed National Coordinating Committee on Drug Abuse included just one page of material on AIDS in its annual report and, until 1991, when the Government Strategy to Prevent Drug Misuse was published, the group rarely met after publishing its initial report (Butler, 1991). Although the Committee largely disbanded, there were some considerable changes in drugs policy at this time. Many of these were initiated by the National AIDS Coordinator, Dr James Walsh, who was appointed by the Department of Health because of his interest in public health, although he had little previous experience in dealing with drugs problems. After Dr Walsh's appointment, the National Drug Advisory Treatment Centre (NDATC) began to offer oral methadone maintenance (physeptone) programmes (in 1987) which allowed opiate dependent users to stabilise their drug use by providing them with an indefinite supply of the heroin substitute. This new harm minimisation philosophy at the NDATC represented a major ideological shift from its previous policy of abstinence and there is some suggestion that the policy imposed by the Department of Health was not always implemented in a user-friendly way (Butler, 1991).
In contrast, a recently established voluntary sector service, developed specifically for drug users, has been very effective and successful. In 1989, the Franciscan Friars in Merchant's Quay (Dublin 8) became increasingly aware of the substantial numbers of people in the immediate locality who were using drugs. One of the Friars, Sean Cassin OFM, had some previous experience in counselling and of dealing with drug users and, initially, he provided information, advice and counselling on a casual basis to drug users in the local area. In 1990, the Merchant's Quay Project was established within the Friary but, because of the fears and prejudice of some members of the religious community to drug users, the project was moved to a larger and more suitable part of the building in 1991 (McKeown et al., 1993). Like the Ana Liffey Drugs Project, the majority of Merchant's Quay clients are male $(65 \%)$, aged between 20 and 30 years, resident in the inner city of Dublin with educational and employment disadvantages and a criminal record (McKeown et al., 1993).

Merchant's Quay has developed a client-led approach to drugs work and now, in addition to other services, offers users condoms and provides a needle and syringe exchange facility which is intended to reduce the incidence of equipment sharing among its clients (Merchant's Quay remains the only voluntary organisation to offer this service). The Project also has a respite centre in a northern suburb of County Dublin where the programme of activities at any time is determined by the needs of the clients. Although, the philosophy at the project is non-judgmental and encourages harm minimisation strategies, Merchant's Quay also provides services for crisis intervention, stabilisation of drug use and detoxification.

Statutory exchange services were first provided by the AIDS Resources Centre at Baggot Street Hospital (Dublin) in 1989. This centre has proved to be the most innovative statutory service in Ireland. Apart from its needle exchange and condom distribution, the centre has also developed an outreach project, a gay men's health project (which was established by a founder of Gay Health Action and AIDS Action Alliance prior to the decriminalisation of acts of anal intercourse), and a women's health project (for sex workers). The services of the AIDS Resources Centre, which became known as the Baggot Street Clinic in 1994, were expanded in 1993 after the Report of the National AIDS Strategy Committee (INASC, 1992) which also resulted in the development of a number of other needle exchange schemes in many of the inner city areas of Dublin where levels of drug use are high.

The National AIDS Strategy Committee Report resulted from a meeting in December 1991 of a 
Table 2. Interviewee characteristics

\begin{tabular}{|c|c|c|c|c|c|}
\hline & Position & Clients & Sector & Sex & $\mathrm{Age}^{\mathrm{a}}$ \\
\hline A & Social worker & Haemophiliacs & Statutory & Female & $30-45$ \\
\hline B & Director & All & Voluntary & Female & $30-45$ \\
\hline $\mathrm{C}$ & GP/GUM consultant & Paying patients & Statutory & Male & $30-45$ \\
\hline $\mathrm{D}$ & Director & IVDUs & Voluntary & Female & $30-45$ \\
\hline $\mathrm{E}$ & Outreach worker & IVDUs & Statutory & Male & $30-45$ \\
\hline $\mathrm{F}$ & Director & Gay men, media etc. & Voluntary & Male & $30-45$ \\
\hline G & Civil servant & Public, media & Statutory & Male & $>45$ \\
\hline $\mathrm{H}$ & Volunteer & IVDUs, & Voluntary & Male & $<30$ \\
\hline I & Outreach worker & Gay men primarily & Statutory & Male & $30-45$ \\
\hline J & Prevention, education & All & Voluntary & Female & $<30$ \\
\hline K & Director & $\begin{array}{l}\text { All, clients primarily } \\
\text { IVDUs }\end{array}$ & Voluntary & Male & $30-45$ \\
\hline $\mathrm{L}$ & Social worker & $\begin{array}{c}\text { Attendants at GUM } \\
\text { clinic }\end{array}$ & Statutory & Male & $30-45$ \\
\hline
\end{tabular}

${ }^{a}$ The age of respondents was divided into three categories, less than 30 years, 30-45 years and over 45 years.

group that included among its membership, staff from both the voluntary and statutory AIDS services. In its April 1992 report, a total of 17 recommendations were made on the care and management of people with AIDS. The focus of most of these proposals was on the organisation of primary health care and clinical treatment but there were also recommendations on related issues such as welfare entitlement, retraining and discrimination. The report included a proposal for the establishment of satellite clinics outside of the hospital setting and in areas with greatest need for the treatment of HIV + people and, especially, drug users. In addition, Community Drug Teams were to be created to serve the needs of intravenous drug users and to include a GP, outreach worker, public health nurse, treatment agency representative and social worker among its members. However, although specific measures were announced and general statements issued concerning the intent of the government in the Programme for Partnership Government, (1993-1997), the status of the report, in terms of the implementation of its recommendations, remains unclear and, despite plans to meet frequently, the Committee has only met twice since its report was published in 1992.

\section{CONSTRAINTS ON PREVENTION}

\section{Design}

The analyses of the constraints on preventative actions that follow form part of a wider study investigating the ways that attitudes to gay sexuality, drug use and HIV/AIDS can influence the nature of services provided both to those who are HIVinfected and to those at risk (see Smyth, 1995). An intensive (qualitative) research methodology was developed for this purpose and involved data collection through in-depth semi-structured interviews with key personnel in relevant health agencies (see previous section) and organisations in Ireland between January 1993 and February of the follow- ing year (see Table 2). Table 2 describes the characteristics of the interviewees firstly in terms of their professional role; the targeted client group of that organisation and its health sector status. Secondly, some personal details about the sex and age are described.

The semi-structured interviews produced an extensive narrative of individual perspectives on the development of policy and the provision of services for people affected by this disease within the specific Irish context. The interviews were initially considered separately to maintain fidelity to individual integrity but, following this introductory analysis, the interviews were then pooled and examined collectively to draw out their common themes (see Atkinson and Farias, 1995) and hence to identify the issues involved in providing HIV and AIDS services in Ireland.

A number of themes emerge from this analysis and are detailed in Smyth (1995). Those which are pertinent to this study are the influence of the Catholic Church and the role of national culture in hindering the delivery of preventative actions. More particularly, religious influences emerged in relation to the role of beliefs and emotions. In the case of the former, Catholic teaching raises questions of morality with respect to attitudes about sex and sexuality. Moreover, the influence of religion extends to the emotions of many people who may be disempowered through their feelings of guilt and fatalism with regard to their sexual activities. What follows examines how these subthemes, together with ideas of Irish national culture, have shaped attitudes towards condom use, celibacy and monogamy and, therefore, health education.

\section{Faith and morals}

Politicians have long accepted the authority of the Catholic hierarchy to speak on issues of faith and morals and, therefore, discussions about sex and sexuality have largely been stifled (O'Brien, 1992; Whyte, 1984). The Catholic views on condom 
use have been made clear in the past (see Cooney, 1986) and, despite calls for the Church to accept the need for condoms to prevent the transmission of HIV, there has been relatively little change in recent times. Indeed, the Church has suggested that, rather than reducing levels of HIV infection, the wider availability of condoms would only serve to heighten the problem. They believe that rather than weaken their resolve, AIDS should reinforce Catholic teaching on both contraception and sex outside the union of marriage:

Making condoms freely available does not get to the root of the problem. It serves only to worsen it. The whole condom propaganda encourages sexual promiscuity...This campaign threatens to weaken public morality (Reidy, 1990, p. 8).

May it [AIDS] help us to realise that the Church's doctrine that sexual intercourse belongs only in marriage is indispensable (Reidy, 1990, p. 11)

Indeed, in 1987, the Catholic bishops issued a statement that reinforced these teachings:

The only reliable safeguard against contracting the [HIV] virus by sexual means is through faithfulness to one's partner in marriage and through self-denial and self-restraint out of marriage (quoted in Power, 1987, p. 112).

Interviewees involved in AIDS prevention work have long been aware of the intransigence of the Church's attitude towards condom use. Rarely, however, has this attitude, in itself, caused a problem. The Church has always been steadfast in its position and workers, therefore, either ignore the teaching of the clergy or work around it:

...for all the priests and sisters who are...quite free to hand out condoms or are quite free to work with people, the Church don't agree with that and their response to safer sex is celibacy and a one-person relationship, and their response to substance abuse is complete abstinency because you shouldn't be abusing your mind. That's Church teaching and that's Church's understanding (Interviewee, $\mathrm{H}$ ).

However, despite the teachings of the Catholic Church, all the interviewees agreed that most people in Ireland would have had little problem in buying condoms, especially in the metropolitan areas. Indeed, one interviewee said that "anyone with a grain of common sense could get a condom" (Interviewee, G).

More problematic for AIDS workers have been the features of Catholicism that are culturally embedded. Despite increased liberalism over the last decade, sex is still seen as "dirty". For women in Ireland, in particular, this notion is reinforced through the instruction of the Church. Celibate priests are imbued with the pastoral leadership of the community and part of their teaching includes a devotion to the Virgin Mary, who is believed to have become the mother of Christ through an immaculate conception. Such teaching has ensured that, until recently, discussions around sex remained largely taboo. Indeed, the first major problem in promoting safer sex that was identified by seven of the interviewees was not condoms but the difficulty of dealing with the wider sexual dimension to HIV and AIDS in a largely traditional, Catholic and conservative society:

I think when you consider, in Irish society, the whole concept of sexuality traditionally is not up there at all for discussion, there is no discourse on sexuality in the Irish context, not any significant discourse (Interviewee, F).

...in Ireland, the first thing that I would identify as a problem is the sexual dimension to HIV and AIDS, whether it be sexual intercourse or sexual orientation. That would still remain to be one of the biggest problems (Interviewee, $\mathrm{K})$.

Although Catholic teaching has been a major influence on the development of AIDS services, equally important and perhaps more unique to Ireland, have been the indirect influences of Catholicism which proliferate Irish thinking.

\section{Fate and guilt}

The perceptions of sexual behaviour described above are not unique to Irish Catholicism but the Church in Ireland also has a strong system of beliefs regarding fate, guilt and shame which are not necessarily found in Catholic teaching elsewhere in the world (Hume, 1987; O'Brien, 1992). The notion of fate was expressed by one interviewee who worked with drug users when he suggested that, unlike drug users in the United Kingdom, intravenous drug users (IVDUs) in Dublin felt that their becoming HIV + was "unavoidable" (Interviewee, E). Another worker claimed that users actually "felt a sense of relief" when they were received a positive diagnosis because, once again, they felt that they would eventually be infected through their habit and that there was little that they could do to protect themselves in the long term (Interviewee, D). Indeed, the government's advertising campaigns have often served to reinforce this message. The early campaigns, in particular, stressed the association between HIV/AIDS and death while offering no advice on how to protect oneself:

And the whole thing like of death, the emphasis in many of them was about death...which has been proven time and time again that that kind of morbid approach to the topic turns people off, you know they switch off, they don't assimilate it...And I think what we need to do with condom advertisements...is not to show the dangers. Yes, tell what the dangers are but show the product fairly you know, use this, this is what it's all about, use this in a correct and responsible way, you know, like to protect you from infection (Interviewee, F).

...do it in a way that is non-threatening for people, gets the message across but is non-threatening. Don't turn around and say to people if you go out and sleep with somebody you are going to get HIV and AIDS. Talk about it, if you do go out and sleep, acknowledge the fact that people do have sex and that if people are going to be sexually active then there are ways and means in which they can actually prevent themselves from becoming positive... (Interviewee, K) 
Fate, however, is only one aspect of this system of beliefs. Guilt is perhaps an even more prominent feature of religion in Ireland. Indeed, as a result of the Church's teaching on sex, people who become infected with HIV are seen by many to have brought it upon themselves:

It's like when I go out and talk in schools and you very often you get the question like, well if people are permissive and they are going out and having sex and they are aware of HIV and AIDS and they get it, type of thing, it is like setting up the guilt scenario again...[but] you can have sex with somebody [and] as long as you adopt safer sex practices you can prevent yourself from becoming positive (Interviewee, K).

People who are HIV + , or who have are living with AIDS, may therefore be seen as "guilty" and, in some sense, deserving of their infection:

Maybe inherently there is still the feeling and I think that still in this country that AIDS is a disease of people who deserve to get it, homosexuals and, em, drug addicts... (Interviewee, G).

In an ecclesiastical publication, for example, Reidy (1990, p. 4) stresses this point by highlighting that people who become infected through their own fault will ultimately be causing their own premature death:

a person who feels that he or she became infected in a context of total moral innocence may react very differently from a person who feels guilty of some fault...the person who is conscious of moral fault may feel that some kind of ultimate penalty has been incurred. This person knows he or she is to die because of his or her own act.

The idea of guilty and innocent victims is certainly not unique to Ireland (see, for example, Grover, 1990; Treichler, 1988) but, equally, it is not simply a view of those involved with the Church. One interviewee, for example, recalled a radio programme where similar views were expressed and where HIV infection was seen as a punishment for earlier behaviour:

This woman phoned in [to a radio show] and was saying well all these people bring it on themselves and...the presenter of the programme...asked her how would she feel if it was her child and she said that she would feel that they brought it on themselves and she wouldn't want to know them (Interviewee, K).

*Although ironic consciousness has been specifically recognised in Ireland, the morality espoused by the New Right in Britain was highlighted by one interviewee as showing similar inconsistencies:

...that may not necessarily be just an Irish situation. In England, at the moment, you have the situation where there is "back to basics" and yet every week we're learning about some Tory minister or MP who has just been caught out. Double standards apply right across the board but in the Irish context I think it very much has to do with this Catholic education, Catholic guilt, Catholic association with things that causes, em, confusion, you know, that's the problem (Interviewee, $\mathrm{K})$.
Even those people who feel trapped by the intensity of Catholicism in Ireland and choose to reject the teaching of the Church rarely escape from its influence. A Catholic upbringing is said to have "the power of capturing a soul for life" (Ryan, 1984, p. 98). Fogarty et al.'s (Fogarty et al., 1984) study suggested that while the Irish are, on one hand, contented they are also "full of uneasiness and selfcritical introspection" (p. 98) which manifests itself as guilt, even in those who choose not to attend mass. Such feelings of guilt do not encourage assertive behaviour and are, therefore, not likely to empower an individual to negotiate safer sex or abstain from drug use (O’Brien, 1992):

The guilt thing is very prevalent in Irish society...you feel guilty for being yourself, you feel guilty for em, you're made feel guilty for being sexually active, you know...I was brought up as a Roman Catholic and I have made a conscious decision not to be a Roman Catholic any more, em. But I know, I can see in myself, in my own character, the guilt traits that are inherent because of the fact that I was brought up as a Roman Catholic. For example, my mother doesn't let me forget the fact that I was brought up as a Roman Catholic and how could I possibly make the decision to not be a Roman Catholic any more, you know, that type of thing but, at the same time, my mother doesn't go to mass, so it's a double standard that happens as well, again more complications on top of an issue (Interviewee, K).

As the interviewee suggested, although guilt is a prominent feature of Irish Catholicism, many people in Ireland, while maintaining their religion and usually attending mass, also feel free to ignore Catholic teaching when it seems impractical or when it is in conflict with their own beliefs (Fogarty et al., 1984). This dual dimension to the Irish character has been recognised by many commentators (see Fogarty et al., 1984). Indeed, Éamon de Valera is reported to have observed that you could say what you liked in England so long as you did the right thing, but that you could do what you liked in Ireland so long as you said the right thing (Lee, 1984). Elsewhere, this double standard has been termed ironic consciousness, the say/do dichotomy and is recognised in psychology as cognitive dissonance, a condition where there are internal contradictions between a person's beliefs and their behaviour (Bullock and Bruner, 1988; Lee, 1984). This peculiarity of the Irish was commented on by other interviewees:*

...and the double standards are, "well, because I want to be accepted by people, em, I will say one thing but behind it all I will do something else," d' you know? (Interviewee, $\mathrm{K})$.

The ability of many Irish people to ignore Catholic doctrine where it seems impractical would appear to be a useful tool in the development of an AIDS education campaign but, in fact, the fine balance between people's beliefs and their behaviour has proved problematic for workers. The implementation of AIDS campaigns has involved a far wider 
discussion of issues than simply the prevention of HIV transmission, including discussions about sex, sexuality, drug use and the nature of Catholicism itself:

You see, the issue to my mind should be straightforward in dealing with, but the problem with that is that, em, it's fudged and it's clouded over with so many other complications which it is very difficult finally to get down to what the real issue is...Again, the whole thing around, em, freedom around, say sexuality and things like that, in all its forms. This, again, is an influence from the Church, a very strong influence from the Church (Interviewee, K).

The Catholic Church can, therefore, be seen to have a strong influence on Irish attitudes to sex, sexuality and hence AIDS. Indeed, the inspiration of Catholic teaching continues to permeate many aspects of the government's response to AIDS and is particularly evident in its educational and informative materials. Much of this material has tended to reflect the values espoused by the Catholic Church and put particular emphasis on personal responsibility. For example, the first booklet produced by the Department of Health was launched in May 1987 and, while it attempted to tackle many of the issues surrounding HIV and AIDS, in line with Catholic teaching, it also included a statement on celibacy:*

Of course, abstaining from sex altogether is obviously a certain way of avoiding the sexual transmission of HIV infection (Department of Health, 1987, p. 7).

Similarly, the Departments of Health and Education have collaborated in the production of an education pack, intended for use in schools, to teach young people about the risks of HIV infection. Inevitably, there was extensive debate amongst workers as to the appropriate content of the pack and indeed the information offered is heavily laden with morality with the emphasis being on one-person relationships, celibacy and personal responsibility. Nonetheless, although many workers expressed quite serious reservations about the content of the pack, they acknowledged that new ground had been broken by mentioning condoms and by not overemphasising celibacy and monogamy.

One problematic aspect of educating young people about HIV and AIDS has been finding a suitable teaching time to introduce the issues because "they don't do life skills and sex ed. is still non-existent in schools" in Ireland (Interviewee, J). Although the topic is usually dealt with in the context of a wider Health Education programme, about $70 \%$ of the 14 18 year age group, who are taught about HIV/AIDS, are informed about infection in religious education

\footnotetext{
*Similarly, while it acknowledged that condoms had a role to play in HIV prevention, it did not explain their use despite evidence that simple information giving is insufficient to combat the "cultural ambivalence" towards condoms in Ireland (Butler and Woods, 1992, p. 69).
}

lessons (Personal Communication, T. A. Gorman, Senior Psychologist, Department of Education, Dublin). In itself, this is not a problem, but the Church in Ireland still plays an important role in the general education of young people and, particularly, in their religious education which is often taught by priests and nuns. Clearly, this may influence the way that the issue is dealt with, in that "nuns can hardly advocate condom use" (Interviewee, C). Hence, there is a certain amount of anxiety surrounding the ways in which the information is disseminated with teachers imparting many of their own perspectives and possible prejudices in their teaching:

Sometimes when you're in there, you like, meet teachers in the staff room who would have very conservative ideas...Sometimes it might be worth while doing sessions with the teachers as well [laughs]. I mean, I actually believe that, that teachers need absolute training...that gets them in touch with their feelings, their prejudices and to recognise how they can impair and affect the kind of message that they are putting across to young people...because I think the information in the pack is only as good as its deliverer and the system of delivery, or the mechanism of delivery, and their dubious content of source (Interviewee, F).

The government, therefore, have been very cautious in their approach to information giving. Catholic teaching has been a major influence on the production of materials and indeed, the government have tried to avoid what are perceived as sensitive political and moral issues, such as the sending of targeted information to people who are at high risk of exposure to HIV infection.

\section{Insularity and the external threat}

One of the main themes that emerged in the government's education campaign was the emphasis that was placed on the threat from HIV that came from abroad. While information giving through television advertising and the production of an education package formed the principal components of the government's approach to AIDS education, they also produced posters and a video to inform people about HIV infection. The poster consisted of a black background with large white letters spelling out, "AIDS: Don't bring it home, casual sex spreads AIDS". It was "situated, by and large, in ferry ports and airports" (Interviewee, F) and is said to have been located next to the rabies posters (Interviewee, E). The forbidding black poster suggests that once again the intention was to stress the serious implications of casual sex, which could lead to death. However, the wording and location of the posters also suggests that the government believed that the threat from HIV came from abroad and not from within its own borders:

...they didn't particularly want to do very much about AIDS in this country. Their perception of AIDS was that it was a disease of homosexuals, American homosexuals and, eh, they didn't really believe there was much homosexuality in this country...they saw it as a kind of oddity disease (Interviewee, G) 
In fact, however, “...there was a lively gay community...in Dublin fifteen years ago..." (Interviewee, E) and HIV was indigenous in the Irish population by at least 1986.* However, despite this, the educational materials produced in 1987 , and updated in 1991, like the posters, also emphasised the external threat of HIV. There, young people were asked to discuss the issues raised in case studies. Their careful wording suggests that the writers did not feel that young Irish people would choose to have sex outside of marriage and, indeed, it would only be "foreigners" that would tempt them. Similarly, by implication, it is only the "foreigners" who are carriers of HIV and not John or his Irish friends:

John and two friends have got summer jobs in a hotel in a seaside town. One night, John is working late. His two friends have a night off. When he finishes, they are waiting for him full of excitement. They say they have been to a pub and have met up with three foreign girls who are really cool and with it. They are camping near the beach and they have invited the boys to a beach party and to spend the night with them. The boys say they have bought beer and that they are going to have a great time because they know the girls want to have sex. They want John to come so that the numbers will be even.

Mary and her two friends have got summer jobs in a hotel in a seaside town. The town is full of tourists...All the girls are being taken out by foreign tourists. Mary meets a lovely French fellow called Marc. One night when they are together he becomes very passionate and wants her to come up to his room with him. Mary has to make a fast choice (Lesson 4, Departments of Health and Education, 1991).

This continual emphasis on the external threat from HIV and AIDS caused concern among some workers. Two felt that it was typical of the government's general attitude, whereby civil servants and other bureaucrats were fearful of taking a leading initiative. They described the policy of the Irish government as "exporting the problem" (Interviewees E and K). However, more commonly, many of the people interviewed, who were involved in education, felt that such an approach was acceptable because they considered it a reasonable representation of the situation in Ireland:

Well, I can understand that, it is a possibility. I suppose what they were getting at was the, you know, a lot of girls who would be in sixth year at school...And, at that age, when girls are 17, 18 and they are going off on holiday with their friends. And, I mean, they are more likely to experiment when they are out of the country and they are

*Evidence for this comes from both the interviewees and from epidemiological data (see Smyth et al., 1996a):

"Anyway, we, in 85-86, tested 500, no how many did we test? I can't honestly remember, we identified, let me put it this way, 503 people who were infected with the HIV virus, all of them, most of them, were Irish. And, eh, so it could no longer be said here, by the people in the department, that it was purely an imported infection and not of any great consequence. We had obviously indigenous HIV in the country. If it was identified in 1985, it had been here since the late 1970s" (Interviewee, G). away from the pressures and then there are other pressures when you are on holidays... (Interviewee, J).

It is perhaps unsurprising that people were accepting of the notion of a foreign disease because few people in Ireland know someone who has been affected and, indeed, in the early days, the image of AIDS as a peculiar disease was reinforced by reports in the press. Despite an epidemiology that suggested otherwise, the media continued to represent AIDS as a disease of gay men, who, as a community, remained almost invisible to a large proportion of the Irish population, especially outside the main urban areas.

Governments elsewhere have also tried to attribute blame for this disease to other nations and as such have been accused of racist motivations (see, for example, Nelkin and Gilman, 1988). In Ireland, however, the emphasis on the threat from "foreigners" reflects the fear that this disease generated but it is also perhaps a reflection of the insularity of the country. Irish people believed that their island status would, in effect, act as a form of quarantine from HIV. Gay Health Action, for example, was the first organisation in Ireland to produce information for people who were concerned about AIDS. However, like the government literature that followed later, they emphasised the external threat of infection by warning others about the risks of having sex with North American men:

...like the first leaflet on AIDS kind of fell into the whole context of saying, you know, AIDS came from somewhere else. It was fairly racist actually, now when you think about it, especially against North Americans (Interviewee, I).

Ireland and its people have had very different experiences to their neighbours in Europe in terms of both colonisation by Britain and by the domination of Catholicism. As a colonised country, it has not experienced the influx of migrants that would lead people to question their cultural codes as, for example, has happened in the United Kingdom. On the contrary, the relative recency of its independence from Britain and its peripheral location in the Protestant heartland of northern Europe has made the Irish very insular and frequently suspicious of their neighbours.

\section{CONCLUSION}

The qualitative analysis has revealed the interplay of Irish Catholicism and identity on prevention to be ambivalent. Foremost, the doctrinal stress on the protection conferred by monogamy as a substitute for the transgressive use of contraceptive barriers would appear to deny one of the most effective personal interventions against HIV infection. Similarly, the reported role of Catholic teaching in curtailing public discourse on sexuality was thought to have hindered the dissemination of health messages 
about HIV/AIDS, fostered fatalism about the avoidance of infection, and reinforced feelings of guilt that discourage self-empowerment. However, it was also recognised that these potentially detrimental consequences of religious authority should be considered alongside Irish attitudes towards Catholic teaching. Cognitive dissonance and the dual dimension to the Irish character, for instance, were often invoked to imply such teaching might easily be ignored when it conflicted with personal interests. Nonetheless, the taking of actions that are counter to religious doctrine is, itself, a constraint on prevention that may not apply in other nations where such pressures are absent. Further, the disempowering nature of some Catholic teaching might deter people from disclosing their risk-related behaviour and, therefore, from taking precautionary actions or being targeted in prevention campaigns.

These arguments highlight the cultural limitations on individual responses to HIV/AIDS but the evidence presented here suggests similar motivations influenced the public domain, where reactions to the epidemic were perceived to be slow and driven by ulterior motives. The government's failure to respond to the initial cases of AIDS in the gay community, for example, was attributed to an institutional homophobia which succeeded in presenting these events as an external threat that did not affect the "general population". The onset of infection among IVDUs was regarded as equally marginal. Indeed, it required the advent of heterosexual incidence to persuade the government both to recognise the Irish dimension to HIV/AIDS and to countenance positive actions like the restricted availability of condoms.

In many other countries, the experience of AIDS has encountered an equivalent initial official lethargy fuelled by similar disregards for the interests of minorities (Berkely, 1993; Brown, 1995). The political reluctance to addressing HIV and AIDS in Ireland, however, may have been nurtured by the cultural embeddedness of Catholicism and the Church's unwillingness to engage with this disease, or the people affected, in a conspicuous manner. Together these actions seem to have delayed the implementation of effective actions for longer than elsewhere and such hesitation may assume a special importance in the case of HIV where, when combined with the long incubation period, such a lag allows the infection to become established in communities prior to early diagnoses of AIDS (May et al., 1989). Indeed, in Ireland, it has been suggested that HIV was indigenous prior to the implementation of preventative actions and, therefore, such actions may have had a relatively minor impact on the interruption of transmission (Smyth et al., 1996b).

Despite such concerns about the constraints on the development of preventative actions, the gay community in Ireland responded to AIDS early in the epidemic when the first cases of the disease were being recognised in the United States and the U.K. Such early responses emerging from the voluntary sector lacked the financial resources available to the public campaigns given later but their highly targeted nature suggests that their impact may have been substantial at least within the gay community. While these responses were led by a small number of individuals, there can be little doubt of the wider impact that AIDS has had on Irish society. In the shadow of this disease, a new openness has evolved around the issues of sex and sexuality and hence the 1990s have seen a shift away from Ireland's obsession with its past, an acknowledgement of many of its current day problems and a new questioning of the authority of the Catholic hierarchy.

Acknowledgements - I would particularly like to thank Richard Thomas for his comments and advice on this and earlier drafts of the paper. In addition, thanks to two anonymous referees for their helpful comments. Funding for this work was provided by a postgraduate research studentship from the Economic and Social Research Council, whose support I would like to acknowledge.

\section{REFERENCES}

Atkinson, S. and Farias, M. F. (1995) Perceptions of risk during pregnancy amongst urban women in Northeast Brazil. Social Science \& Medicine 41, 1577-1586.

Berkeley, C. (1990) Cairde: a support service for people affected with AIDS. Journal of the Irish Colleges of Physicians and Surgeons 19(1), 25.

Berkely, S. (1993) AIDS in the developing world: an empirical overview. Clinical Infectious Diseases 17(2), s329-336.

Brown, M. (1995) Ironies of distance: an on-going critique of the geographies of AIDS. Environment and Planning, D: Society and Space 13, 159-184.

Bullock, A. and Bruner, J. S. (1988) Cognitive consonance and cognitive dissonance. In The Dictionary of Modern Thought, eds A. Bullock, O. Stallybrass and S. Trombley, pp. 137-8. Fontana, London.

Butler, S. (1991) Drug problems and drug policies in Ireland: a quarter of a century reviewed. Administration 39(3), 210-233.

Butler, S. and Woods, M. (1992) Drugs, HIV and Ireland: responses to women in Dublin. In AIDS: Women, Drugs and Social Care, eds N. Dorn, S. Henderson and N. South, pp. 51-69. Falmer Press, London.

Coogan, T. P. (1987) Ireland Since the Rising. Greenwood Press, Westport, CT.

Cooney, J. (1986) The Crozier and the Dáil: Church and State 1922-86. Mercier Press, Cork.

Dean, G., Lavelle, P., Butler, M. and Bradshaw, J. P. (1984) Characteristics of Heroin and Non-heroin Users in North Central Dublin Area. Medico Social Research Board, Dublin.

Dean, G., O'Hare, A., O'Connor, A., Kelly, M. and Kelly, G. (1985) The opiate epidemic in Dublin, 19791983. Irish Medical Journal 78(4), 107-110.

Dean, G., Lavelle, P., O'Kelly, F. D., Power, B. and Hillery, I. (1992) Follow up of a cohort of intravenous heroin users in North and South Central Dublin and in Dun Laoghaire. Irish Medical Journal 85(1), 9-10.

Department of Health (1987) AIDS Education Materials. Department of Health, Dublin. 
Department of Health (1995) HIV/AIDS Statistics to 31st December 1995. Department of Health, Hawkins House, Dublin.

Departments of Health and Education (1991) AIDS Education Materials, 2nd edn. Department of Health, Dublin.

Dyck, I. (1990) Context, culture and client: geography and the health for all strategy. Canadian Geographer 34, 338-341.

Fogarty, M., Ryan, L. and Lee, J. (1984) Irish Values and Attitudes: The Irish Report of the European Value Systems Study. Dominican, Dublin.

Freedman, D. (1989) Medical ethics and the patient with AIDS. Journal of the Irish Colleges of Physicians and Surgeons 18(3), 169-170.

Gay Health Action (GHA) (1986) AIDS Information Booklet. GHA, Dublin.

Grover, J. Z. (1990) AIDS: keywords. In The State of the Language, eds C. B. Ricks and L. Michaels, pp. 142162. University of California Press, Berkeley.

Hume, B. (1987) Time for moral renaissance. In AIDS: Meeting the community challenge, ed. V. Cosstick, pp. 143-146. St. Paul, Slough.

INASC (1992) Report of the Sub-committee on the Care and Management of Persons with HIV/AIDS to the National AIDS Strategy Committee. Irish National AIDS Strategy Committee, Dublin.

Kearns, R. A. (1996) AIDS and medical geography: embracing the other? Progress in Human Geography 20(1), 123-131.

Kirp, D. L. and Bayer, R. (1992) AIDS in the Industrialised Democracies: Passions, Politics and Policies. Rutgers University Press, New Brunswick, NJ.

Krieger, N. and Margo, G. (1994) AIDS: The Politics of Survival. Baywood, New York.

Lee, J. (1984) Reflections of the study of Irish values. In Irish Values and Attitudes: The Irish Report of the European Value Systems Study, pp. 107-124. Dominican, Dublin.

May, R. M., Anderson, R. M. and Blower, S. M. (1989) The epidemiology and transmission dynamics of HIVAIDS. Dadalus 118(2), 163-201.

McKeown, K., Fitzgerald, G. and Deeham, A. (1993) The Merchants' Quay Project: A Drugs/HIV Service in the Inner City of Dublin: 1989-1992. Franciscan Friary Merchant's Quay, Dublin.

Nelkin, D. and Gilman, S. L. (1988) Placing blame for devastating disease. Social Research 55(3), 361-378.
O'Brien, O. (1992) Responding to Minority Community Needs-The Irish and HIV: Assessing the Role of Networking-Interim Report. PIAA, London.

O'Hare, A. and O'Brien, M. (1992) Treated Drug Misuse in the Greater Dublin Area: 1990. Health Research Board, Dublin.

O'Keefe, F. N., Barnville, H. T., Otridge, B., Powderly, W., Alton, B. and Dervan, P. (1983) Acquired Immunodeficiency Syndrome with Kaposi's Sarcoma in Ireland. Irish Journal of Medical Science 152(9), 353356.

O'Leary, C. and Hesketh, T. (1988) The Irish abortion and divorce referendum campaigns. Irish Political Studies 3, 35-45.

Peillon, M. (1982) Contemporary Irish Society: An Introduction. Gill and Macmillan, Dublin.

Power, B. (1987) AIDS in Ireland. In AIDS: Meeting the Community Challenge, ed. V. Cosstick, pp. 112-114. St. Paul, Slough.

Quinlan, M. (1991) Voluntary Response to AIDS in Ireland. Gay Men's Health Project, Dublin.

Reidy, M. (1990) AIDS Education and Sexual Morality. Veritas, Dublin.

Ryan, L. (1984) The changing face of Irish values. In Irish Values and Attitudes: The Irish Report of the European Value Systems Study, pp. 95-106. Dominican, Dublin.

Smyth, F. M. (1995) Social and epidemiological constructions of HIV/AIDS in Ireland. Unpublished Ph.D. dissertation, University of Manchester.

Smyth, F. M. and Thomas, R. W. (1996a) Preventative action and the diffusion of HIV/AIDS. Progress in Human Geography 20(1), 1-22.

Smyth, F. M. and Thomas, R. W. (1996b) Controlling HIV/AIDS in Ireland: the implications for health policy of some epidemic forecasts. Environment and Planning $A$ 27, 99-118.

Treichler, P. A. (1988) AIDS, gender and biomedical discourse: current contests for meaning. In AIDS: The Burdens of History, eds E. Fee and D. M. Fox, pp. 190266. University of California Press, Berkeley.

Trench, B. and Brennan, P. (1980) Poverty in Ireland. Magill April, 10-31.

World Health Organisation-European Community (WHO-EC) Collaborating Centre (1991) Current AIDS Literature, Vol. 4. Bureau of Hygiene and Tropical Disease, London.

Whyte, J. H. (1984) Church and State in Modern Ireland, 1923-1979, 2nd edn. Gill and Macmillan, Dublin. 